\title{
MONITORING OF DRINKING WATER RESERVOIRS OF KOPARGAON CITY WITH SPECIAL REFERENCE TO ALGAL FLORA AT YESGAON, DIST. AHMEDHNAGAR MAHARASHTRA (M.S.), INDIA
}

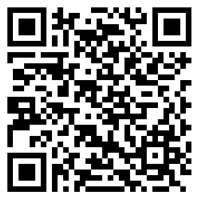

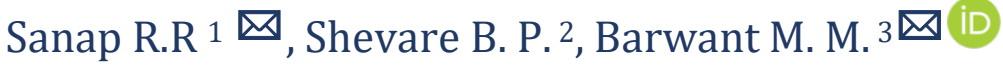 \\ 1, 3 P.G. Department of Botany, R.B.N.B. College, Shrirampur, Dist. Ahmednagar, (M.S.), India \\ 2 S.S.G. M. College, Kopargoan, Dist. Ahmednagar, (M.S.), India
}

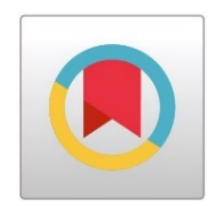

DOI: https://doi.org/10.29121/granthaalayah.v8.i9.2020.1344

Article Type: Research Article

Article Citation: Sanap R.R, Shevare B. P., and Barwant M. M.. (2020). MONITORING OF DRINKING WATER RESERVOIRS OF KOPARGAON CITY WITH SPECIAL REFERENCE TO ALGAL FLORA AT YESGAON, DIST. AHMEDHNAGAR MAHARASHTRA (M.S.), INDIA. International Journal of Research GRANTHAALAYAH, 8(9), 16-21. https://doi.org/10.29121/granthaa layah.v8.i9.2020.1344

Received Date: 30 August 2020

Accepted Date: 21 September 2020

Keywords:

Monitoring

Drinking Water

Reservoirs

Algal Flora

Kopargaon

\section{ABSTRACT}

Algal collection from 5 drinking water storage reservoirs of Kopargaon city was carried out for one year. A total 39 genera and 62 species belonging to four classes were encountered during investigation period. Present studies revealed that, algal population was not found homogenous throughout the year, but it showed seasonal variation. During monsoon the algal population recorded was less, which increases in winter and found more in summer season. Chlorophyceae was found to be the dominant group throughout the investigation period in all storage tanks consisting of large number of genera and species. Many planktonic, some benthic and epiphytic algae were encountered during investigation period at all five water storage reservoirs. The commonly occurred genera were Ankistrodesmus, Closterium, Cosmarium, Spirogyra, Ulothrix from class Chlorophyceae, while from Cyanophyceae, Merismopedia, Microcystis, Oscillatoria, and Lyngbya are dominating forms. Desmids wear found in dominant condition in all storage tanks indicating unpolluted condition of water. Maximum population of Cosmarium was recorded during summer season, while Closterium species were recorded throughout the year. Other genera recorded were Staurastrum, Xanthidium, Euastrum, Micrasterias, Arthrodesmus, Desmidium, etc. Diatoms were recorded more in number during winter, while Euglenophycean members were sparsely reported only in summer. During present studies tremendous variations in Desmid diversity was noticed during summer and winter as compared to monsoon season.

\section{INTRODUCTION}

Water is most useful natural resource on the earth. From the origin of universe, water is being remained most important material for civilization. It is one of the vital resources for all kinds of life on the earth. In rural areas, there is more scarcity of water for irrigation as well as drinking purpose particularly in winter and summer seasons.

In many areas of country, large sized ground-based water storage tanks are constructed. These are filled when water is available and then it is used for drinking purposes after purification. These water reservoirs are present in open condition and so the algal flora is growing luxuriously throughout the year in these water reservoirs. When water tanks are at the range of empty, at that time algal blooms are formed. This algal flora imparts the unpleasant

(C) 2020 The Author(s). This is an open access article distributed under the terms of the Creative Commons Attribution License, which permits unrestricted use, distribution, and reproduction in any medium, provided the original author and source are credited. 
odour and greenish colour to drinking water during winter and summer and thus ultimately spoils the drinking water quality.

Many workers has studied many water reservoirs with reference to phytoplankton studies like Tiwari et al., (2001); Pawar et al., (2006); Nandan and Aher (2005 a); Munnawar, (1970) etc. However, the monitoring of drinking water reservoirs of Kopargaon city with special reference to algal flora was remained untouched and so the problem was undertaken for the investigation.

\section{MATERIALS AND METHODS}

Ahmednagar district comes under the rain shadow area of Maharashtra state. Kopargaon city is situated at Northern region of district at the bank of Godavari River. For drinking water purpose, five large sized open water tanks are constructed by Municipal Corporation of Kopargaon at Yesgaon village just $10 \mathrm{~km}$. away from Kopargaon city at Northern side near Irrigation Canal. During canal rotation, these tanks are filled with water. From these tanks, water is lifted through pipeline, purified at Kopargaon and the then supplied to citizens.

Monthly collection of phytoplankton from above mentioned five water storage tanks was carried out for one year during the period May 2016 to April 2017 with the help of plankton net of bolting silk cloth 250 meshes / linear inch, while benthic and epiphytic algal forms were collected separately. All algal samples were preserved in $4 \%$ formaldehyde and Lugol's solution. Microphotographs of some algal forms were taken simultaneously by using research microscope ("Leica DM 1000 LED Microscope) and computer software. Identification of algal flora was carried out with relevant literature like Desikachary, 1969; Prescott, 1962; Sarode and Kamat (1984) and Philipose (1967).

\section{RESULTS AND DISCUSSIONS}

During investigation period, four algal classes were recorded from all five sampling stations. The classes recorded were Chlorophyceae, Cyanophyceae, Bacillariophyceae and Euglenophyceae comprising 17 families, with 39 genera and 62 species (Table 1 and Table 2).

Table 1: Different classes of algal flora with families and no. of Genera and species encountered during investigation period

\begin{tabular}{|c|c|c|c|c|}
\hline Sr. No. & Classes & Families & Genera & Species \\
\hline \multirow[t]{10}{*}{1} & \multirow[t]{9}{*}{ Chlorophyceae } & Scenedesmaceae & 01 & 01 \\
\hline & & Coelastraceae & 01 & 01 \\
\hline & & Chlorellaceae & 01 & 01 \\
\hline & & Oocystaceae & 05 & 05 \\
\hline & & Zygnemataceae & 01 & 02 \\
\hline & & Desmidaceae & 08 & 18 \\
\hline & & Hydrodictyaceae & 01 & 01 \\
\hline & & Ulotricaceae & 02 & 02 \\
\hline & & Oedogoniceae & 01 & 01 \\
\hline & Total & 09 & 21 & 32 \\
\hline \multirow[t]{3}{*}{2} & \multirow[t]{2}{*}{ Cyanophyceae } & Chroococcaceae & 05 & 06 \\
\hline & & Oscillatoriaceae & 03 & 08 \\
\hline & Total & 02 & 8 & 14 \\
\hline \multirow[t]{6}{*}{3} & \multirow[t]{5}{*}{ Bacillariophyceae } & Naviculaceae & 03 & 05 \\
\hline & & Nitzschiaceae & 01 & 02 \\
\hline & & Surirellaceae & 01 & 01 \\
\hline & & Achnanthaceae & 01 & 01 \\
\hline & & Fragilariaceae & 02 & 05 \\
\hline & Total & 05 & 08 & 14 \\
\hline 4 & Euglenophyceae & Euglenaceae & 02 & 02 \\
\hline
\end{tabular}


Sanap R.R, Shevare B. P., and Barwant M. M.

\begin{tabular}{|c|c|c|c|}
\hline Total & 01 & 02 & 02 \\
\hline Gross Total & 17 & 39 & 62 \\
\hline
\end{tabular}

Table 2: Details of Algal flora encountered during investigation period at all sampling stations:

\begin{tabular}{|c|c|c|}
\hline Sr. No & Class & Name of Algal form \\
\hline 1 & \multirow[t]{32}{*}{ Chlorophyceae } & Crucigenia quadrata Morren \\
\hline 2 & & Coelastrum spharicum Naegeli \\
\hline 3 & & Chlorella vulgaris Beyerinck \\
\hline 4 & & Oocystis irregularis (Petkof) Printz \\
\hline 5 & & Kirchneriella lunaris (Kirch.) Moebius \\
\hline 6 & & Ankistrodesmus fulcatus (Corda.) Ralfs. \\
\hline 7 & & Tetrastrum heteracanthum (Nordst.) Chod \\
\hline 8 & & Actinastrum hantzschii Var. fluviatile, Schroeder \\
\hline 9 & & Spirogyra crassa Kutetzing \\
\hline 10 & & Spirogyra regularis \\
\hline & & Closterium diana var. arcunatum. Ehr \\
\hline 11 & & Cosmarium pseudobroomei Wolle. \\
\hline 13 & & Cosmarium scrobiculosum Borge \\
\hline 14 & & Cosmarium constrictum Delp. \\
\hline 15 & & Cosmarium nitidulum De. Nordstedt \\
\hline 16 & & Cosmarium cranatum Ralf. \\
\hline 17 & & Cosmarium pachydermum Lund \\
\hline 18 & & Cosmarium pyramidatum Berb. \\
\hline 19 & & Cosmarium contractum var. incrassatum Scott \& Prescott. \\
\hline 20 & & Euastrum pictinatum inevolutum West \& West \\
\hline 21 & & Euastrum dubium Nageli \\
\hline 22 & & Euastrum inermius (Nordstedt) Turner \\
\hline 23 & & Euastrum spinulosum Delponle. Var. bellum Scott and Prescott \\
\hline 24 & & Desmidium grevillii (Kuetz.) De. Bary \\
\hline 25 & & Micrasterias radiata, Hass \\
\hline 26 & & Xanthidium cristatum var.uncinatum Hass \\
\hline 27 & & Arthodesmus convergens Ehr. \\
\hline 28 & & Actidesmium Hookeri Reinsch \\
\hline 29 & & Hydrodictyon reticulatum (L) Lagerheim \\
\hline 30 & & Ulothrix variabilis Kuetzing \\
\hline 31 & & Ulothrix subconsticta G.S.West \\
\hline 32 & & Oedogonium latisculum Tiff. \\
\hline 33 & \multirow[t]{14}{*}{ Cynophyceae } & Chroococus limneticus Lemm. \\
\hline 34 & & Merismopedia punctata Meyen \\
\hline 35 & & Microcystis aeruginosa Kuetz. \\
\hline 36 & & Gloeothece linearis Naegeli. \\
\hline 37 & & Gloeothece linearisvar. Compostri G.M.Smiths \\
\hline 38 & & Dactylococopsis raphidiodesHansg \\
\hline 39 & & Oscillatoria ornate Kutz ex Gomant \\
\hline 40 & & Oscillatoria rubscence Dc. ex Gomant \\
\hline 41 & & Oscillatoria subbrevis Schemidle \\
\hline 42 & & Oscillatoria chalybea(Materns.) Gom \\
\hline 43 & & Phoromidium ambiguum \\
\hline 44 & & Lyngby anordgardhii Wille \\
\hline 45 & & Lyngbya majuscule Harvey ex Gomant \\
\hline 46 & & Lyngbya martensiana Meneghini ex Gomont \\
\hline
\end{tabular}


Monitoring of Drinking Water Reservoirs of Kopargaon City with Special Reference to Algal Flora at Yesgaon, Dist. Ahmedhnagar Maharashtra (M.S.), India

\begin{tabular}{|c|c|c|}
\hline 47 & \multirow[t]{14}{*}{ Bacillariophyceae } & Navicula pygmaea Kuetz \\
\hline 48 & & Navicula rhynchocephala Kuetz. var. elongata Mayer \\
\hline 49 & & Navicula cupsidata Kuetz. \\
\hline 50 & & Mastogloia blatica Grun. \\
\hline 51 & & Gomophonema lanceolatum Ehr.v. insiginis (Greg.) Cleve \\
\hline 52 & & Nitzschia tryblionella Hantzsch v. levidensis (W. Smith) Grun. \\
\hline 53 & & Nitzschia filliformis (W.Smith ) \\
\hline 54 & & Gyrosigma kuetzingii (Grun.) Cleve \\
\hline 55 & & Achanthes microcephala (Kuetz.) Grun \\
\hline 56 & & Fragilaria leptostauron(Ehr.) Hustedtv.woerthensis Mayer \\
\hline 57 & & Fragilaria ungeriana Grun. \\
\hline 58 & & Fragilaria pinnata Her.fsurotunda Mayer \\
\hline 59 & & Fragilaria intermedia Grun. \\
\hline 60 & & Synedra ulna (Nitz.) Ehr. \\
\hline 61 & \multirow[t]{2}{*}{ Euglenophyceae } & Euglena elastic Prescott \\
\hline 62 & & Phacus caudate var. Ovalis. Drezepolski \\
\hline
\end{tabular}

Many planktonic, some benthic and epiphytic algal species were recorded during investigation periods from all five sampling sites. The algal classes recorded during present studies were Chlorophyceae, Cyanophyceae, Bacillariophyceae and Euglenophyceae. In general, planktonic algae were dominant in all water reservoirs when the water level is low. It might be due to availability of many nutrients for the growth of algal flora in addition to bright sunlight and much quantity of carbon dioxide. Chakrabarty et al. (1959) reported maximum no. of phytoplankton during summer and minimum during winter from river Jamuna at Allahabad,

During present investigation, Chlorophyceae was found to be the dominant group. A total 9 families comprising 21 genera and 32 species has been recorded from this group. The commonly occurred genera were Ankistrodesmus, Closterium, Cosmarium, Desmidium ,Euastrum, Ulothrix and Spirogyra.

The distribution pattern of different species of Desmids was influenced by physico-chemical parameters of water. A total 08 genera and 18 species of this family were recorded during investigation period (Table. 1) and represented by genera like Closterium, Cosmarium, Euastrum, Xanthidium, , Micrasterias, Arthrodesmus, Desmidium and Actidesmium

It was observed that, during summer and winter seasons due to bright sunlight and high temperature vigorous growth of Desmids was recorded. Similar results were obtained by Whitford and Schumachur (1963). For the optimum growth of Desmids the $\mathrm{pH}$ is playing very important role. The $\mathrm{pH}$ ranging from 6.5 to 7.5 was found to be suitable for the growth for Desmids. However, abundant occurrence of desmids in acidic $\mathrm{pH}$ was observed by Griffith (1928). It was also observed that lighter period and less dark period was suitable for best growth of desmids. Similar observation was made by Vidyvati (2007). That's why desmids were flourished during late winter and summer seasons.

Our results matches with that of Sheeba and Ramanujan (2005) who reported the dominace of Chlorophyceae from different water reservoirs. It was observed that Chlorophyceae was flourished during late winter and summer season. Mani and Sarvana (2006) also observed the dominancy of Chlorophyceae from river Kaveri. According to Sarojini (1994), the dominance of Chlorophyceae was due to the influence of high temperature and nitrate content.

Cyanophyceae was second largest group reported during present investigation and represented by 8 genera and 14 species belonging to two families. The commonly recorded genera were Merismopedia, Microcystis, Oscillatoria and Lyngbya. During present studies it was observed that, Cyanophycean members were found to be flourished during late winter and summer. Our results co-relates with that of Moore (1977) who opined that, during summer more number was recorded and might be due to availability of more free carbon dioxide, sunlight, nitrates and phosphates concentration. Lowest number of algal taxa of BGA was recorded in monsoon months particularly in months of July, August and September. More water nutrition with bright sunlight increases the algal population during summer. According to Pawar et al. (2006) high organic matter, high temperature and low DO favours the growth of Blue Green Algae. 
Bacillariophyceae was third group encountered during study periods. This group comprises 14 species belonging to 8 genera. The commonly recorded genera of this class were Fragillaria, Nitzschia, Synedra and Navicula. It was observed that, the growth and abundance of Diatoms was found in more number during winter season. Ragothaman and Jaiswal (1995) also opined that, cold conditions and lower values of temperature and DO favours the growth of diatoms. Our results coincides with that of Kelly (1998) and Rajkumar (2005). Venkateswarlu (1983) opined that decrease in level of DO, highly organic matter favours the growth of Diatoms. During present investigation, it was observed that change in water flow, temperature and transparency affects the growth and abundance of algae.

Euglenophyceae members were rarely found particularly during summer and when water level in the storage tanks declines. It was represented by Euglena and Phacus in some water tanks only.

\section{CONCLUSION}

During present studies, it was observed that Chlorophycean algal flora was found in dominant condition followed by Diatoms and Blue Green Algae. Euglenophycean memers were very rarely found during summer when water storage tanks are on the range of empty. Desmids are found in dominant condition throughout the year. The bright sunlight, alkaline water favored the growth and population of Desmids during summer season.

\section{SOURCES OF FUNDING}

This research received no specific grant from any funding agency in the public, commercial, or not-for-profit sectors.

\section{CONFLICT OF INTEREST}

The author have declared that no competing interests exist.

\section{ACKNOWLEDGMENT}

Authors are grateful to the Principal, R. B.N.B. College, Shrirampur, Dist. Ahmednagar for his keen interest and constant encouragement. Thanks, are also due to the Principal, S.S.G.M. College Kopargaon and Principal, Sanjivani Arts, Commerce, and Science College, Kopargoan, Dist. Ahmednagar for continuous support and encouragement.

\section{REFERENCES}

[1] Chakrabarty, R. D., Roy, P. and Singh, S. B. 1959. A quantitative study of the plankton and the physico-chemical conditions of the river Jamuna at Allahabad in 1954-55. Indian J. Fish., 6 (1): 186-203.

[2] Desikachary, T. V. 1969. Cyanophyta. Indian Council of Agricultural Research, New Delhi.1- 688 pp.

[3] Griffiths, B. M. 1923. The phytoplankton of bodies of fresh water and the factors determining its occurrence and composition. J. Ecol., 2: 184-213.

[4] Kelley, M.G. 1998. Use of trophic diatom index to monitor eutrophication in rivers. Wat Res. 32:236-242.

[5] Mani, S. and Saravana, B. 2006. Distribution of algae from Bhavani to Erode in the river Kaveri as indicators of water quality. Eco. Env. and Cons., 12(1): 129-132.

[6] Moore, J. W. 1977. Seasonal succession of algae in a eutrophic stream in Southern England. Hydrobiologia, 53(2): 181-192.

[7] Munnawar, M. 1970. Limnological studies on freshwater ponds of Hyderabad, India. The Biotope, Hydrobiologia, 35(1): 127-162.

[8] Nandan, S. N. and Aher, N. H. 2005 a. Species diversity in algal flora of Haranbaree dam and Mosam river of Naglan (Maharashtra). Eco. Env. and Con., 11(3-4): 551-553

[9] Pawar, S. K., Madlapure, V. R. and Pulle, J. S. 2006. Phytoplanktonic study of Sirur dam water. Taluka Mukhed in Nanded district, India. J. Eco, Env. and Cons. 12(1): 163-166.

[10] Philipose, M. T. 1967. Chlorococcales. Indian Council of Agricultural Research, New Delhi. 1- 365 pp. 
[11] Prescott, G. W. 1962. Algae of the Western Great Lakes Area. Wm. C. Brown Co. Dubeque, Iowa. 1- 935 pp.

[12] Ragothaman, G. and Jaiswal, R. N. 1995. Studies on the hydrobiology of Tapi river from Jalgaon region (Maharashtra) with reference to phytoplankton. Poll. Res., 14(2): 181-194.

[13] Rajakumar, N. 2005. Biodiversity of diatoms of a few lenticanal lotic habitats of Coimbatore district. Indian Hydrobiology, 7 supplement: 101-104.

[14] Sarode, P. T. and Kamat, N. D. 1984. Freshwater Diatoms of Maharashtra, Sai Krupa Prakashan, Aurangabad.: 1-324 pp.

[15] Sarojini, Y. 1994. Composition, abundance and distribution of phytoplankton in sewage and receiving harbour water at Visakhapatnam. Phykos, 33(1\&2): 137-146.

[16] Sheeba, S. and Ramanujan, N. 2005. Phytoplankton composition and distribution in Ithikkara river, Kerala. Indian Hydrobiology, 8(1): 11-17.

[17] Tiwari, A., Upadhyay, R. and Chauhan, S. V. S. 2001. A systematic account of Chlorococcales from Kitham lake, Agra. Phykos, 40(1\&2): 103-105.

[18] Venkateswarlu, V. 1983. Taxonomy and ecology of algae in the river Moosi. II. Bacillariophyceae. Bibliotheca Phycologica- J. Cramer. 66:1-41.

[19] Vidyavati, 2007. Biodiversity in Desmids. Indian Hydrobiology, 10(1): 27-33.

[20] Whitford, L. A. and Schumacher, G. J. 1963. Communities of algae in North Carolina streams and their seasonal relations. Hydrobiologia, 22(1\&2): 133-196. 